\title{
Effect of AGIS on Implementation of Electronic Land Administration in FCT, Abuja Nigeria
}

\author{
Oruonye, E.D. ${ }^{1, *}$, and Menwo Ukechi Wilson-Osigwe ${ }^{2}$, Fatima Tukur ${ }^{3}$, Y. M. Ahmed ${ }^{4}$ \\ 1,2\&4Department of Geography, Faculty of Social Sciences, Taraba State University \\ Jalingo, Taraba State, Nigeria \\ ${ }^{3}$ National Open University of Nigeria (NOUN) \\ Abuja, Nigeria \\ *Corresponding author's email: eoruonye [AT] gmail.com
}

\begin{abstract}
Land administration in Abuja includes processes of land registration, cadastre, valuation and land inventory. Every country in the world pursues these activities in one form or another irrespective of the stage of development. Developing countries particularly, Nigeria are overwhelmed by challenges of land management and administration. Recent efforts to secure tenure and enhance real property markets are under pressure from increasing demand and competition for land. Effort at implementing land administration reform in the Federal Capital Territory (FCT) have led to inefficiency, incoherent and poor land management. This has undermined the huge potentials and global competitiveness in the sector. This study assesses the effectiveness of Abuja Geographic Information Systems (AGIS) on the implementation of electronic land administration in the FCT. Descriptive survey method was adopted in carrying out this study. Data collection involved sample of 150 applicants/beneficiaries of land, drawn across seven districts to determine how electronic land administration system in the FCT has improved the practice. The findings of the study revealed that electronic land administration in AGIS does not address unequal land distribution. Also, management, acquisition and disposal of public land follow unclear procedures and are not applied equitably and transparently. Formal land delivery takes an inordinate amount of time under the existing frameworks and land fees are unaffordable to many residents in the FCT. Based on the findings, the study recommended the empowerment of the Land Use and Allocation Committee (LUAC) to ensure fairness and equity in land acquisition processes, reorganizing the AGIS workflow, installation of state-of-the art technology for efficiency that will make the processes and procedures for acquisition of land clear to the general public. The study also recommended active participation of key stakeholders through public hearings and citizen's forums.
\end{abstract}

Keywords--- Abuja, AGIS, Electronic, Federal Capital Territory and Land Administration

\section{INTRODUCTION}

In Nigeria, all lands are vested in government and held in trust on behalf of the Nigerian people. As the nation's capital city, Abuja covers about 8,000 square kilometres of land, and is geographically located at the centre of the country. It became the seat of government in 1991 when the Federal Government relocated its capital from the densely-populated Lagos state, which, nonetheless, remains the nation's commercial nerve centre. With a population of about 1.4 million people according to the 2006 census, Abuja has the $18^{\text {th }}$ highest population density in the country and is often considered as one of the fastest growing capital cities in Africa by government officials.

As a result of the desire of the federal government to hasten the development of the new capital city, land allocation was handled by the Land Allocation Committee (LAC) appointed by the Minister of the Federal Capital Territory (FCT), while city planning was methodically implemented in the early 1990s in line with the Abuja Master Plan. The Plan was, however, not faithfully implemented even by government authorities, resulting in erratic allocations and approvals, land use abuses, multiple allocations of plots and encroachments. In a short while, the emergence of slums, squalors, and other random settlement structures across the city in districts like Garki, Wuse, Karu, Mpape, Kubwa, Gwagwalada and Lugbe, to mention a few became an issue of public concern.

Operational processes at the Land Administration Department were also largely manual, which invariably contributed to the "human element" to the allocation of lands. Moreover, the number of litigations and land disputes both between individuals, as well as between government and citizens rose significantly over the years. According to court records obtained from the Federal Capital Territory (FCT) High Court, between 1999 and 2003 there were about 127 cases relating to disputes over ownership of lands within the FCT, while nearly 300 cases related to citizens and businesses filing court cases against the government for demolition of property, revocation of titles, and/or forceful ejection from dwellings. In 2003, the Federal Minister for the Federal Capital Territory (FCT) initiated wide-ranging measures to re-establish the Plan as the basis for the development of the growing city, fuelled by the economic liberalization policies and re-emergence of the Nigerian middle class during that decade. 
The measures included demolition of slums, resettlement and compensation of affected residents, strengthening of existing laws and enactment of new ones, as well as the establishment of institutions - including the Abuja Geographic Information System (AGIS) office - to support the renewed implementation of the Master Plan. AGIS was set up in 2003 principally to undertake a complete computerization of the cadastral and land registry of the FCT. GIS is believed to be relevant to land administration, in the sense that remote sensing technology and communication networks permit more effective resource management, mitigation of environmental risks, while facilitating greater transparency and monitoring of environmental abuses, as well as enforcement of environmental regulations. AGIS is also expected to facilitate the development of the land transfer market while establishing an efficient and sustainable system of land administration in the capital city. Ultimately, AGIS is expected to lead to improvement in the security of tenure, simplify the process of land acquisition, and foster prudent land management practices.

In many countries, improvements to existing land administration systems are driven by developments in technology. Land and property datasets grow ever larger as populations expand and the need for land information in support of development becomes ever more urgent. In order to provide both administrators and data users with accurate and up-to-date information about the land, more rapid and efficient systems must be developed for data collection, update, and distribution. Improved surveying techniques, database management systems, standards to support data integration, and telecommunications will help to solve many of these problems. Till date, GIS technology has become more sophisticated, required specialist users, and has been difficult to integrate into mainstream information technology. This has restricted its widespread adoption by those involved in land administration. As GIS and associated technologies mature and more data become available in computer form, the use of GIS for integrating land-related data becomes more opportune. Increased openness and integration of data are, however, more than technical issues and are often seen as a threat rather than as an opportunity.

The effective implementation of any system of land administration requires the cooperation of a diverse number of government agencies and private sector organizations. Land administration is often viewed as a central government responsibility. As a consequence, involvement of local government or the private sector may be seen as unacceptable since quality control becomes more complex. Furthermore, the adoption of common standards - for instance agreement by all agencies to use the same unique property reference number may necessitate changes in internal procedures that are expensive to implement and of no direct benefit to the work of the individual agency.

The efficient and effective land administration and its associated resources depend upon the availability of good land information. The need for information, which is the basic necessity for carrying out any planning, development and management activity, can hardly be over-emphasized. With regards to the developing nations and emerging states with inadequate resources, the need for having a reliable information base is even more important. The absence of the proper land records in the real estate market is another difficulty being faced by many developing countries. The reason may be unclear delimitation of individual or group rights, insecure ownership etc. The necessity for functioning land market opens the way not only for private development but also for public land acquisition and other means of ensuring that land is available for dwelling and other urban needs. In this way, the development and implementation of country-wide digital land information system is an area that needs urgent attention. To this, many states in Nigeria are computerizing their land records and creating large database with the use of GIS. Through GIS, land-related data are now being integrated, analyzed, and distributed in ways that until recently were not possible.

In respect of land administration, urban planning and housing allocation services, one of the ICTs most commonly adopted is the Geographic Information System (GIS), typically designed to capture, store, analyze and depict different kinds of geographic and geo-spatial data. Although GIS and its associated technology pre-dates the concept of electronic governance, its adoption as a tool in the provision of public housing and land allocation services, as this study shows, can considerably improve the efficiency and effectiveness of delivery of these services, hence our consideration as a study in electronic governance. This study used the case of Nigeria's capital city, Abuja where the Federal Capital Territory administration has established the Abuja Geographic Information System (AGIS) office as an infrastructure to provide land administration services, housing allocations, urban planning and, to some extent, revenue generation.

\section{Research Hypotheses}

The following null hypotheses are formulated for validation in the study:

$\mathrm{HO}_{1}$ : There is no significant positive impact of AGIS on Equity, Fairness and Accessibility of land allocation through Electronic Land Administration in the Federal Capital Territory.

$\mathrm{HO}_{2}$ : There is no significant positive impact of AGIS on efficiency and effectiveness of land allocation through Electronic Land Administration in the Federal Capital Territory.

$\mathrm{HO}_{3}$ : There is no significant positive impact of AGIS on transparency and accountability of land allocation through Electronic Land Administration in the Federal Capital Territory

$\mathrm{HO}_{4}$ : There is no significant positive impact of AGIS on subsidiarity and depoliticization of land allocation through Electronic Land Administration in the Federal Capital Territory

\section{Description of the study area}

Geographically, the Federal Capital Territory (FCT) lies between latitude $8^{0} 25^{\prime}$ and $9^{0} 20^{\prime}$ North of the equator and longitude $6^{0} 45^{\prime}$ and $7^{0} 39^{\prime}$ East of the Greenwich meridian. It covers a land area of about 8,000 square kilometres. The 
creation of the Federal Capital Territory (FCT) dates back to February, 1976 with the promulgation of decree No.6 entitled 'Federal Capital Territory 1976'. From then on, the area measuring 8,000 square kilometres was carved out from three existing states (Niger, Plateau and Kogi) of the federation. The Territory was then divided into nine development areas namely: Abaji, Bwari, Yaba, Kwali, Kuje, Rubochi, Karshi, Abuja Municipal and Gwagwalada. In 1987, the nine development areas were reconstituted into six (6) local governments namely; Abaji, Gwagwalada, Kuje, Kwali, Bwari, and the Municipal. The unofficial metropolitan population of Abuja is well over 3,000,000, but the population as at 2012 is 2,245,000 making it the fourth largest urban area in Nigeria after Lagos, Kano and Ibadan (FCDA, 2018).

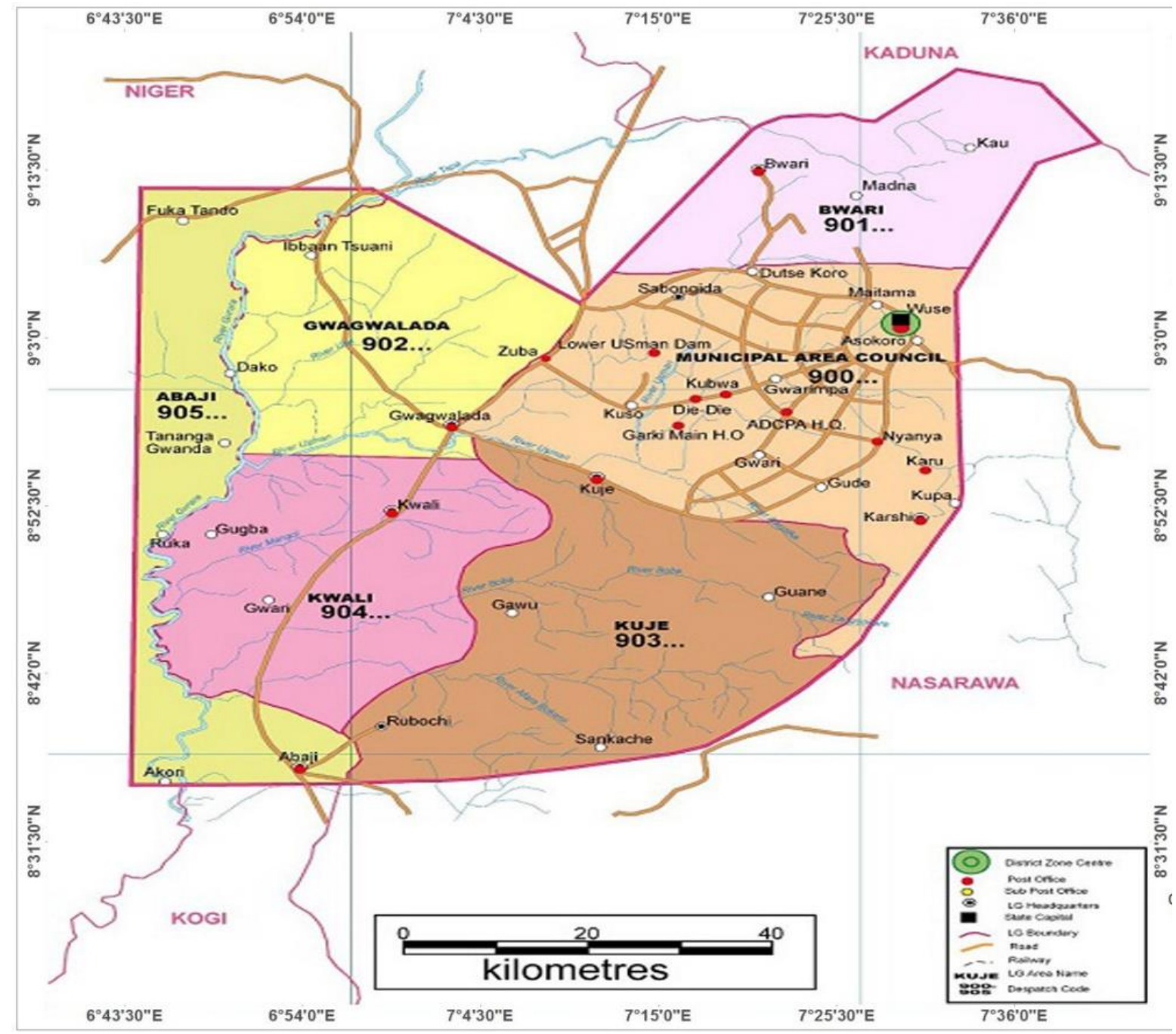

Source: FCDA

Figure 1: Map of Federal Capital Territory (FCT) showing the six area councils.

\section{MATERIALS AND METHODS}

The study use primary and secondary data. This primary data was gathered using both open ended and closed ended questionnaires. Secondary data were sourced from published and unpublished materials. These included works of various scholars, maps, records, reports and other necessary information from the relevant technical and administrative departments and agencies of the Federal Capital Territory Administration (FCTA). The Abuja Geographic Information System (AGIS) and Federal Capital Development Authority (FCDA) were major data sources. Questionnaire administration, interviews and observation form the bulk of the primary data. These were collected on site and directly from numerous field surveys.

The study population covered six area councils in FCT as defined by the main administrative units forming its basic structure. The study used stratified sampling design. Stratified sampling was used by creating different groups in the population sample; that is, title holders and applicants. After stratifying, the study used random sampling method to choose respondents from each stratum.

Questionnaires were administered according to three stage clusters sampling with three phases from Abuja Metropolitan Area Council (AMAC) as phase one, phase two and phase three. The first phase began with learning and understanding 
the purposes and processes of land administration system as presented in the literature and practice. The second level has to do with identifying the system of land administration in the Federal Capital Territory (FCT). The third level then identified users of such instrument for the specific purpose of land management. These aided the separation of their needs and determine what gaps exist in the data required and provided.

Each of phases one and two was divided into another set of cluster. Two districts were each selected from phase one and phase two and one in phase three. Using random sampling procedure 30 respondents which comprises of both title holders and applicants were selected in each district giving a total of 150 for the whole AMAC.

Before administering the questionnaire, pilot survey was carried out to arrive at common terms and derive certain pertinent questions. This was done through initial contacts with prospective respondent. The institutional survey was carried out to ascertain individual tasks and departmental responsibilities in the land administration process. Under this survey, a total of 7 interviews were carried out in the seven (7) core land related department and agencies of FCDA, FCTA, as well as AGIS. These included Abuja Metropolitan Management Council, Department of Urban \& Regional Planning, Department of Resettlement \& Compensation, Satellite Town Development Agency, Department of Development Control, Department of Parks and Recreation, and Abuja Geographic Information System. The respondent from the institutional survey are management staff of each department.

The study involved the use of data from socio-economic survey in addition to secondary information from AGIS and FCDA. The socio-economic survey addressed land title-holders (beneficiaries) and applicants in two (2) districts from Phase 1 (Wuse and Garki district), phase 2 (Jabi and Mabushi) and one district in phase 3 (Gwanrinpa)

Descriptive statistics in the form of frequencies, percentages and chi-square were used for analysis in the study. Statistical Package for Social Sciences (SPSS) computer software (version 18) was used to present the data in the form of frequency, tables and percentages. The hypotheses were tested using Chi square. The formula is as follows;

$\mathbf{X}^{2}=($ of-E1)2IEf

Where

Summation

Of $=$ Observed frequency

$\mathrm{Ef}=$ Expected frequency

A contingency Table is constructed to calculate the expected frequency, using the formula:

\section{$\frac{\mathrm{RT} \times \mathrm{KT}}{\mathrm{N}}$}

Where RT is Row Total, KT is Column Total and N is Grand Total.

Degree of freedom is given by $(\mathrm{R}-1)(\mathrm{R}-1) \mathrm{R}=\mathrm{Row} \mathrm{K}=$ Column

At $1 \%$ level of significance

The null hypothesis is rejected if $\mathrm{X} 2 \mathrm{C}>\mathrm{X} 2 \mathrm{t}$ and the alternative hypotheses is accepted.

The null hypothesis is accepted if $\mathrm{X} 2 \mathrm{C}<\mathrm{X} 2 \mathrm{t}$ and the alternative hypothesis is rejected.

\section{RESULT OF THE FINDINGS}

\section{Principle of Equity, Fairness and Accessibility}

Equity and fairness as a good governance principle in land administration requires that access to land be equitable and fair. That is, land administration systems should remove unnecessary barriers to people's rights to a secured tenure for which no group within society should be marginalized. The findings from the study reveals that AGIS framework has not engendered equity or fairness in land administration in FCT, Abuja. Out of about $100 \%$ of those who applied for land, only $37.21 \%$ were successful. About $60 \%$ of the successful applicants indicated they had to use insiders to access land, while $40 \%$ had to follow up their allocation by paying-off. The $62.79 \%$ who were unsuccessful met the requirement for allocation but were not allocated any land. Under an ideal situation, access to land by all should be equitable and fair; and guaranteed, irrespective of status. Access to land is essential for people to raise and stabilize their incomes and to participate in economic development. The mechanisms for accessing and acquiring land must be accessible, unbiased and efficient. In this regard, AGIS structure does not comply with the principle of accessibility as shown in Table 1 . The study findings 
reveal that within the period of study, only 49,604 approvals were made out of a total of 82,744 applications for land at the FCT. AGIS was established in 2004 and recertification exercise commenced in 2006 whereby individuals who applied for land since the inception of FCT and were not given was asked to update their records. This explains the reason for the highest activity of allocation at $120.54 \%$ and $128.43 \%$ in 2012 and 2013 . The sharpest decline was in 2008 at $12.37 \%$.

Table 1. Rates of Application and Allocation

\begin{tabular}{|l|l|l|l|}
\hline Year & Total Applications & Total Allocation & Allocation Rate (\%) \\
\hline 2006 & 1651 & 302 & 18.29 \\
\hline 2007 & 5383 & 2654 & 49.30 \\
\hline 2008 & 5463 & 4554 & 83.36 \\
\hline 2009 & 3190 & 2323 & 72.82 \\
\hline 2010 & 1559 & 333 & 21.36 \\
\hline 2011 & 19071 & 3747 & 19.65 \\
\hline 2012 & 14982 & 18060 & 120.54 \\
\hline 2013 & 9881 & 12690 & 128.43 \\
\hline 2014 & 9177 & 1136 & 12.37 \\
\hline 2015 & 12387 & 3805 & 30.72 \\
\hline Total & 82744 & 49,604 & \\
\hline
\end{tabular}

Source: Abuja Geographic Information System, 2019

The result on modes of acquisition of land as shown in Table 2 reveal that about $33 \%$ of the respondents purchased their land from individuals who either were allocated the land or had bought land, while only $31.51 \%$ were allocated land. $70 \%$ of the respondents who purchased land had to bypass the lengthy bureaucratic waiting period under the formal procedures. There was a general response of paying more to access land through purchase and these group were at risk of buying fake or forged allocation documents from land speculators.

Table 2. Mode of Acquisition

\begin{tabular}{|c|c|c|c|c|c|c|c|c|c|c|c|}
\hline \multirow[t]{3}{*}{$\mathrm{S} / \mathrm{N}$} & \multirow{3}{*}{$\begin{array}{l}\text { Districts } \\
\text { FCC } \\
\end{array}$} & \multicolumn{10}{|c|}{ Mode of Acquisition } \\
\hline & & \multicolumn{2}{|c|}{ Allocation } & \multicolumn{2}{|c|}{ Market Purchase } & \multicolumn{2}{|c|}{ Transferred by } & \multicolumn{2}{|l|}{ Gift } & \multicolumn{2}{|c|}{ Others } \\
\hline & & No. & $\%$ & No. & $\%$ & No. & $\%$ & No. & $\%$ & No. & $\%$ \\
\hline 1 & Wuse & 11 & 5.02 & 8 & 3.65 & - & - & - & - & - & - \\
\hline 2 & Garki & 15 & 6.84 & 7 & 3.20 & - & - & - & - & - & - \\
\hline 3 & Mabushi & 5 & 2.28 & 10 & 4.57 & - & - & - & - & - & - \\
\hline 4 & Jabi & 8 & 3.65 & 10 & 4.57 & - & - & - & - & - & - \\
\hline \multirow[t]{2}{*}{5} & Gwarimpa & 4 & 1.82 & 11 & 5.02 & - & - & - & - & - & \\
\hline & Area Council & & & & & & & & & & - \\
\hline 6 & Bwari & 13 & 5.94 & 16 & 7.31 & - & - & - & - & - & - \\
\hline 7 & Gwagwalada & 13 & 5.94 & 10 & 4.57 & - & - & - & - & - & - \\
\hline \multicolumn{2}{|c|}{$\begin{array}{l}\text { Total = } 219 \\
(100 \%)\end{array}$} & 69 & 31.51 & 72 & 32.88 & 0 & 0 & 0 & 0 & 0 & 0 \\
\hline
\end{tabular}

Source: Field Survey, 2019

Few estate developers also had formal access to land. About 75\% (Table 3) of the estate developers made purchases from the open market. The $25 \%$ of the developers that had formal access paid for services obtained at AGIS contrary to the norm. High costs in accessing land impact negatively on the cost of doing business i.e. affects the prices and sizes of houses for sale. There is also denied access to land for prospective investors in mass housing. 
Table 3: Acquisition of Land from AGIS (Estate Developers)

\begin{tabular}{|l|l|l|l|}
\hline \multirow{2}{*}{ S/N } & Estate Developer & \multicolumn{2}{|l|}{ Acquisition of Land from AGIS } \\
\cline { 3 - 4 } & & Yes & No \\
\hline 1 & Urban Shelter Ltd & 1 & 4 \\
\hline 2 & Standard form Dev. Co. Ltd & - & 1 \\
\hline 3 & Efab Properties Ltd & 1 & 5 \\
\hline 4 & Triarch Nig. Ltd. & 1 & - \\
\hline 5 & Trans project Housing project & - & 1 \\
\hline 6 & Prism Consult Nig. Ltd & - & 1 \\
\hline 7 & Global formwork Nig. Ltd & 1 & - \\
\hline 8 & & $4(25 \%)$ & $12(75 \%)$ \\
\hline
\end{tabular}

Source: Field Survey, 2019

In terms of ease of access by institutions, only $25 \%$ of respondents acknowledged easy access to land. Reasons given by the $75 \%$ included difficult processes and procedures and long bureaucracy among others. The opinion of most of the respondents on access to land at AGIS is determined by patronage.

Table 4. Opinion on Institutional Performance on Accessibility to Land

\begin{tabular}{|l|l|l|l|}
\hline \multirow{2}{*}{ S/N } & \multirow{2}{*}{ Departments } & \multicolumn{3}{|l|}{ Has AGIS Improved } \\
\cline { 3 - 4 } & & Yes & No \\
\hline 1 & Urban \& Regional Planning & - & 1 \\
\hline 2 & Development Control & - & 1 \\
\hline 3 & Survey and Mapping & - & 1 \\
\hline 4 & Resettlement \& Compensation & - & 1 \\
\hline 5 & Engineering Services & 1 & - \\
\hline 6 & Abuja Environmental Protection Board (AEPB) & - & 1 \\
\hline 7 & Satellite Towns Development Agency (STDA) & - & 1 \\
\hline 8. & Parks and recreation & 1 & - \\
\hline & TOTAL & $2(25 \%)$ & $6(75 \%)$ \\
\hline
\end{tabular}

Source: Field Survey, 2019

There are also difficulties expressed by individual applicants. The study findings in Table 4 reveals that about $58 \%$ of the respondents are of the opinion that the establishment of AGIS comes with a lot of difficulty. Bureaucracy and cumbersome procedures and an over-centralized system are the perceived reasons for difficulty associated with the establishment of AGIS. Other respondents suggested administrative bottlenecks and the non-existence of mechanism for detecting malpractices. As major concerns, land administration under AGIS therefore share similarity with the conventional procurement system. No visible improvement exists.

\section{Principle of Transparency}

Land administration reform entails that land allocation is undertaken transparently without ambiguity in authoritative roles, responsibilities and method of land allocation, appropriation and disposal. Full disclosure on the use of public land is a necessity and land management is to be guided by appropriate rules and regulations; and by openness. The findings of the study does not reveal any form of compliance of AGIS to this requirement according to respondents opinion. AGIS neither publishes up-to-date information on land allocations nor the income from premium and processing charges. The excuses are tied to the conventional policy which does not allow for the publishing of land transactions. The lack of feedback presupposes the existence of corrupt tendencies. Public offer of information on land transactions and proceeds as a best practice ensures transparency, integrity and accountability.

\section{Principle of Affordability}

Affordability as a good governance principle in land administration requires that costs of acquiring land and services should be affordable and reasonable as well and should not be overly burdensome. High transaction cost are disincentives to investors. This variable was analyzed to determine people's capabilities to pay for land processing and transaction fees. Table 5 shows categories of old and new rates of land charges and premium in the FCT and the area council. The reasons provided by AGIS for increasing land charges is that, FCT plan is believed to be lagging and that since 33 years from inception, less than $25 \%$ of the development targets has been achieved. Officials advanced that the global economic 
meltdown has affected the revenue input, therefore it was only sensible that the agency can self-sustain by increasing charges.

AGIS also indicated that payments are made in the bank accounts dedicated to each project and proceeds are used solely for the provision of infrastructure in the district paid for. The fees according to AGIS is said to be below the current black market rate and the intention is to transfer the advantage currently enjoyed by speculators and racketeers to the end users of land in particular and the polity at large. Most categories of payment for land transaction are affected but the major increase is on the premium. The effect of inconsistencies and high charges levied from 2009 - 2010 brought about low turnout of clients coming to pay for land charges, which forced the authority to review downward the land charges. The current land charges are still considered to be very high.

Table 5. Land Transactions Fees in the FCT

\begin{tabular}{|l|l|l|l|l|l|}
\hline S/N & Transaction & Size & $\begin{array}{l}\text { Old Rates ( N) } \\
(2006-2015)\end{array}$ & $\begin{array}{l}\text { New Rates } \\
(\mathrm{p} 4)(015)\end{array}$ & $\begin{array}{l}\text { Latest Rates } \\
(2015)\end{array}$ \\
\hline 1. & Land application processing fees & & & & \\
\hline & a. Residential & All sizes & 50,000 & 100,000 & 100,000 \\
\hline & b. Commercial & All sizes & 20,000 & 100,000 & 100,000 \\
\hline 2. & Premium charges & & Per m2 & Per m2 & Per m2 \\
\hline & $\begin{array}{l}\text { Central Business District (CBD) } \\
\text { /Commercial }\end{array}$ & & 2,000 & 20,000 & 10,000 \\
\hline & $\begin{array}{l}\text { (fully serviced) Residential (Maitama, } \\
\text { Asokoro and Wuse II }\end{array}$ & & 2,000 & 18,000 & 8,000 \\
\hline & $\begin{array}{l}\text { (fully serviced) Garki I \& Wuse II, } \\
\text { Jabi, Guzape and Utako }\end{array}$ & & 2,000 & 15,000 & 6,000 \\
\hline & $\begin{array}{l}\text { (Partially Serviced) Katampe, Jahi } \\
\text { Gwarimpa, Gudu, Mabushi, Wuye \& } \\
\text { Durumi }\end{array}$ & & 2,000 & 12,000 & 5,000 \\
\hline & $\begin{array}{l}\text { (not serviced) Kaura, Dakibiyu, Kado, } \\
\text { Dape \& other areas }\end{array}$ & & 2,000 & 10,000 & 2,000 \\
\hline & Housing estate & Fully Served & - & 2,500 & 2,500 \\
\hline & Area Council & Residential & 600 & 600 & \\
\hline
\end{tabular}

Source: Abuja Geographical Information System, 2019

The rates of land charges are expensive and very expensive according to $30 \%$ and $50 \%$ of the respondents in the study area. They were of the view that the rates are outrageous and that it is only the well-to-do who can afford to pay for the land charges. Particular reference was made to the cost of certificate of occupancy which is said to be too high.

The study on the rates of monthly income of respondents revealed that about $24 \%$ of the respondents earns above 100,000 , while 35\% earns between 50,000 - 100,000 as monthly income. From the findings of the study, the respondents opined that their income is not sufficient to pay for the land charges even when they are allocated land. Particular reference was made to the cost of certificate of occupancy. Consider for instance, if a land of about 1000 square meter within Phase II (i.e. Guzape) is allocated to an individual with a monthly income of 100,000 , and such an individual is required to pay for certificate of occupancy; assuming such an individual save $20 \%$ of his monthly income that is ( $\$ 20,000)$, that means such an individual will be required to pay 6,000,000 for the certificate of occupancy. At $20 \%$ savings from 100,000, and then it will take such an individual 25 years to be able to pay such an amount of money for Certificate of Occupancy. In Recent time, the total cost of the certificate of occupancy is required to be paid in full as against half installmental payment before development can commence on any land. Thus, the cost of acquiring land and its services are unaffordable and high cost on land charges has encouraged land speculation. The effect is also seen in irregular urban development pattern especially at the peripheral zones of the FCT.

\section{Principle of Effectiveness}

Effectiveness in land administration is concerned with or having the function of accomplishing and executing services delivered to users in a timely manner in accordance with the set service standards. Technical solutions should be based on available capacity and appropriate technology. AGIS structure is not in adherence with the principle of effectiveness. 
Table 6. AGIS Staff Capacity

\begin{tabular}{|l|l|c|}
\hline S/N & \multicolumn{1}{|c|}{ STAFF NOS } & NOS \\
\hline 1 & Lands & 9 \\
\hline $\mathrm{a}$ & Land Officers & 18 \\
\hline $\mathrm{b}$ & Planners & 20 \\
\hline $\mathrm{c}$ & Estates Officers & 2 \\
\hline $\mathrm{d}$ & Legal Officers & 3 \\
\hline $\mathrm{e}$ & Administrative officer & \\
\hline 2 & AGIS & 12 \\
\hline $\mathrm{a}$ & Administrative officer & 13 \\
\hline $\mathrm{b}$ & Account And Audit & 10 \\
\hline $\mathrm{c}$ & Survey & 128 \\
\hline 3 & Contract Staff & $\mathbf{2 1 5}$ \\
\hline & TOTAL & \multicolumn{2}{|c|}{} \\
\hline
\end{tabular}

Source: Abuja Geographical Information System, 2019

Table 6 shows that AGIS staff capacity is made of 215 staff. 87 staff (about 40\%) makes up the permanent staff, while 128 staff (about $60 \%$ ) are contract staff. It has been observed that, a large number of the contract staff, as well as some permanent staff engage in shady practices in land allocation. For instance, 83 staff from AGIS were sacked (with most of them being contract staff) as a result of conniving with fraudulent land buyers to forge documents and input them into the AGIS computer, thus allocating lands to people without the authority of the Minister. There are problems of consistencies, multiple allocation, forgery and abuse of land records. There has been oversight to land administration in AGIS due to services not being executed and delivered to users in a timely manner. As revealed on rates of application and allocation, the total number of land turned out for allocation is small compared to the numbers of applications received.

\section{Performance AGIS}

The rating of AGIS by respondents was considered poor by $71 \%$ of the respondent while those who saw effectiveness in the performance of AGIS was $29 \%$. The reasons given for the poor performance is reflected in the way AGIS undermines the functions of some of these departments. For example, response from the interview in Urban and Regional Planning (JRP) department discloses that when plots are turned out for allocation in AGIS from the department, certain areas in the layout design are reserved for specific purposes, but as soon as it gets to AGIS the reserved areas are carved out for allocation and are usually not reconciled with the URP layout.

The response from survey and mapping department brought to light that, plotting is no longer done on intelligent sheets as it was easier to detect overlaps in allocations. With computerization of land administration, it is easy to feed any information into the system without proper verification; hence there are still cases of forgeries and multiple allocations. The development control department identified the problem of communication gap between her and AGIS. For instance, any time a land title is revoked by AGIS, development control is not informed, despite the fact that some of these title holders do the building setting out of approval. These anomalies downgrade the credibility of the development control unit and create administrative problems for them. Communication gaps is also a problem between AGIS and Parks and Recreation Department as some of the areas earmarked for green are converted into other use and allocated without proper consultation with them. Most of which are not recoverable due to personal interest. Effectiveness, consistency and predictability as a successful operational practices ensure high service standards. 


\section{Principle of Efficiency}

Table 7. Processing for e-Land Acquisition

\begin{tabular}{|l|l|l|l|l|l|l|l|l|l|l|l|l|l|}
\hline S/N & Districts & \multicolumn{9}{l|}{ Processing for Land Acquisition } \\
\hline \multicolumn{2}{|l|}{ Very Easy } & Easy & \multicolumn{2}{l|}{ Okay } & \multicolumn{2}{l|}{ Difficult } & \multicolumn{3}{l|}{ Very Difficult } \\
\hline 1 & FCC Wuse & No 1 & $\begin{array}{l}\% \\
3.33\end{array}$ & No 4 & $\begin{array}{l}\% \\
13.33\end{array}$ & No 3 & $\begin{array}{l}\% \\
10.00\end{array}$ & No 8 & $\begin{array}{l}\% \\
26.67\end{array}$ & $\begin{array}{l}\text { No } \\
10\end{array}$ & $\% 33.33$ \\
\hline 2 & Garki & - & - & - & - & 3 & 10.00 & 11 & 36.67 & 11 & 36.67 \\
\hline 3 & Mabushi & 2 & 6.67 & 1 & 3.33 & 2 & 6.67 & 7 & 23.33 & 14 & 46.67 \\
\hline 4 & Jabi & - & - & 2 & 6.67 & 5 & 16.67 & 11 & 36.67 & 9 & 30.00 \\
5 & Gwarimpa & - & - & 1 & 3.33 & 1 & 3.33 & 14 & 46.67 & 7 \\
\hline
\end{tabular}

Source: Field Survey, 2019

Efficiency as a good governance principle in land administration entails assigning unambiguous institutional responsibility for the land administration service and clear focus on service delivery, which is responsive to user needs in a manner that will build user trust. The overall process of service delivery should be seen as business rather than bureaucratic processes as mentioned earlier to which AGIS is lacking. The survey in Table 7 revealed a total of $39.73 \%$ and $39.73 \%$ of difficult and very difficult procedures for land acquisition totaling $79.32 \%$. The opinion for difficulty in processing for land includes bureaucracy and tedious process. $80 \%$ of the difficult and very difficult processes acknowledged administrative bottlenecks, and unstable policies. About $95 \%$ of the respondents acknowledged that land acquisition processes are not clear, short and simple. $90 \%$ of the respondents also added that uniform service standards are not ensured at the area council's zonal land offices and regular revocation of plots makes the system inefficient.

Table 8. Processing for e-Land Acquisition (Estate Developers in FCT)

\begin{tabular}{|l|l|l|l|}
\hline \multirow{2}{*}{$\mathrm{S} / \mathrm{N}$} & \multirow{2}{*}{ Estate Developer } & Acquisition of Land from AGIS \\
\cline { 3 - 4 } & & Easy & Difficult \\
\hline 1 & Urban Shelter Ltd & - & 1 \\
\hline 2 & Standard Form Devt. Co. Ltd & - & 1 \\
\hline 3 & Efab Properties Ltd & - & 1 \\
\hline 4 & Triarch Nig Ltd & 1 & - \\
\hline 5 & Transproject Housing Project & - & 1 \\
\hline 6 & Prism Consult Nig Ltd & - & 1 \\
\hline 7 & Global Formwork Nig Ltd & - & 1 \\
\hline Total & & $1(14.29 \%)$ & $6(85.71 \%)$ \\
\hline
\end{tabular}

Source: Field Survey, 2019

The opinion of the estate developers on processes and procedure for land acquisition through AGIS was also sought. $85.71 \%$ of the respondents are of the view that it is difficult and that the longer steps in procedure gives more opportunity for corruption and inefficiency. However, $14.29 \%$ of these respondents indicated ease of land acquisition e.g. Triarch Nigeria Ltd is in private partnership with FCDA in delivery of mass housing. The interview with AGIS shows that AGIS is slightly efficient in registering of property transactions which takes 1-2 weeks and only involves the entry of the information into the system, but the processing to acquire the land itself takes much longer and an indefinite period of time.

Table 9. Data on rates of Revocation

\begin{tabular}{|l|l|l|}
\hline S/N & Period & Nos. of Revocation \\
\hline 1. & 2006 & 1939 \\
\hline 2 & $2008-20013$ & 2657 \\
\hline 3 & 2015 & 685 \\
\hline \multicolumn{2}{|l|}{ Total } & 5281 \\
\hline
\end{tabular}

Source: Abuja Geographical Information System, 2019 
Land administration reform requires a consistent and coherent legal framework for efficiency and the general guidance of the rule of law to protect property rights without fear of revocation. The terms of revocation sometimes are not adhered to. Table 9 shows that in 2006 alone, there were about 1,939 land titles which were revoked. 2008-2013 had 2,657 land revocations although the figures may not be absolute as very few have been reinstated. Reason for the revocation according to AGIS includes contravention of terms and condition, non-development, overriding public interest, previous commitment, and cancellation of accelerated development programme amongst others.

It has been observed that $70 \%$ of the revocations are due to non-development. There are lots of title owners especially in phase two and phase three of the FCT who are unable to develop or take physical possession of their land due to no infrastructure, yet they get their titles revoked. Inconsistent legal framework also makes it easy for any ruling government to revoke people's land without unnecessarily due to contravention of terms of Right of Occupancy and Certificate of Occupancy. An efficient land administration system is consistent in its services; there should be no allocation at all in the first place in those districts without infrastructure.

Table 10. Data on Reported Land Cases (2004-2010)

\begin{tabular}{|l|l|l|}
\hline S/N & Complaints & Nos \\
\hline 1 & Revocation & 43 \\
\hline 2 & Demolition & 450 \\
\hline 3 & Encroachment & 1 \\
\hline \multicolumn{2}{|l|}{ Total } & 494 \\
\hline
\end{tabular}

Source: FCDA Legal Unit, 2019

FCDA has a legal unit that attends to land cases. It has been observed that very few cases are reported to them. Most people go directly to the court on issues of land. The survey in Table 10 shows that the legal unit has only 43 cases on revocation from 2008 -2012. From the interview at the legal services unit, it was noted that majority of the complaints received from revocation, demolition and encroachment ends up not been thoroughly attended to. This explains the reason for the few numbers of complaints. There are deficiencies in the system in relation to efficiency and the rule of law.

\section{Test of Hypotheses}

In this section, the study test the hypotheses formulated to ascertain the rejection or acceptance of the null hypotheses. This was done using chi-square $\left(\mathrm{X}^{2}\right)$ statistical techniques. The hypotheses are stated in the null form.

Ho1: There is no significant positive impact of AGIS on Equity, Fairness and Accessibility of land allocation through Electronic Land Administration in the Federal Capital Territory.

Table 11. Chi-square analysis of difference between Equity, Fairness and Accessibility and Electronic Land Administration

\begin{tabular}{|l|l|l|l|l|l|l|}
\hline $\begin{array}{l}\text { No of } \\
\text { respondents }\end{array}$ & \multicolumn{2}{|l|}{ c-land administration } & Df & $\begin{array}{l}\text { Cal X } \\
\text { value }\end{array}$ & $\begin{array}{l}\text { Critical } X^{2} \\
\text { value }\end{array}$ \\
\hline 150 & & Very easy & Difficult & 1 & 2.97 & 3.84 \\
\hline & Applicant & $95(100.7)$ & $156(150.6)$ & & & \\
\hline & Staff & $25(19.6)$ & $24(29.4)$ & & & \\
\hline
\end{tabular}

Table 11 shows that the calculated $X^{2}$ value of 2.96 is less than the critical $X^{2}$ value of 3.84 . Therefore, the stated null hypothesis is up held which mean that there is no significant positive impact of AGIS on Equity, Fairness and Accessibility of land allocation through Electronic Land Administration in the Federal Capital Territory.

Ho2: There is no significant positive impact of AGIS on efficiency and effectiveness of land allocation through Electronic Land Administration in the Federal Capital Territory

Table 12. chi-square analysis of difference between efficiency and effectiveness and Electronic Land Administration

\begin{tabular}{|l|l|l|l|l|l|l|}
\hline $\begin{array}{l}\text { No of } \\
\text { respondents }\end{array}$ & \multicolumn{2}{|l|}{ c-land administration } & Df & $\begin{array}{l}\text { Cal. } \\
\mathrm{X}^{2} \text { value }\end{array}$ & $\begin{array}{l}\text { Critical } \\
\mathrm{X}^{2} \text { value }\end{array}$ \\
\hline 150 & & Very easy & Difficult & 1 & 1.38 & 3.84 \\
\hline
\end{tabular}




\begin{tabular}{|l|l|l|l|l|l|l|}
\hline & Applicant & $85(90)$ & $35(30)$ & & & \\
\hline & Staff & $132(135)$ & $48(45)$ & & & \\
\hline
\end{tabular}

Table 12 shows that the calculated $X^{2}$ value of 1.38 is less than the critical $X^{2}$ value of 3.84 . Therefore, the stated null hypothesis is up held which means that there is no significant positive impact of AGIS on efficiency and effectiveness of land allocation through Electronic Land Administration in the Federal Capital Territory.

Hoz: There is no significant positive impact of AGIS on transparency and accountability of land allocation through Electronic Land Administration in the Federal Capital Territory.

Table 13. Chi-square analyses on transparency and accountability and Electronic Land Administration

\begin{tabular}{|l|l|l|l|l|l|l|}
\hline $\begin{array}{l}\text { No of } \\
\text { respondents }\end{array}$ & \multicolumn{2}{|l|}{ e-land administration } & Df & $\begin{array}{l}\text { Cal } X^{2} \\
\text { value }\end{array}$ & $\begin{array}{l}\text { Critica1 } X^{2} \\
\text { value }\end{array}$ \\
\hline 150 & & Very easy & difficult & 1 & 1.05 & 3.84 \\
\hline Applicant & $90(93.6)$ & $30(26.4)$ & & & & \\
\hline Staff & $144140.4)$ & $36(39.6)$ & & & & \\
\hline
\end{tabular}

Table 13 shows that the calculated $X^{2}$ value of 1.05 is less than the critical $X^{2}$ value of 3.84 . Therefore, the stated null hypothesis is up held which means that there is no significant positive impact of AGIS on transparency and accountability of land allocation through Electronic Land Administration in the Federal Capital Territory.

\section{Implications of lack of Access to land}

\section{DISCUSSION OF FINDINGS}

The consequence of inequitable land distribution and restricted access to land through the official channel results in people finding informal means to cope with their needs, leads to land speculation and encroachment. Land speculation occurs when the demand for land, at the present time or in the near future, outstrips the supply of land. This can be caused by several factors both on the demand side and on the supply side.

On the demand side, land speculation can be triggered by excess liquidity in the financial markets caused either by rapid economic growth or by a lack of opportunities for investors in other sectors of the economy in slow growing economies like that of Nigeria. In either scenario investors invest on a short term to medium term basis in the land market, waiting for prices to increase and sell their tenure at a profit. This is the situation in AGIS; land speculation has driven land prices beyond the productive value of the land. On the supply side land speculation is caused by administrative bottlenecks in the availability of serviced land (land with basic infrastructure such as roads, water, electricity etc.). These bottlenecks are caused by land development in phase or in the transaction phase. Speculation in the land market in FCT has made land unaffordable even for many and they are forced to find shelter illegally which in turn bring about several negative developments including, creation of slums and squatter settlements, environmental deterioration, and an inefficient urban development pattern.

\section{Implications of Ineffectiveness}

Deininger (2004) empirically illustrated that insecure land tenure prevents large parts of the population from realizing the economic and non-economic benefits such as greater investment incentives, transferability of land, improved credit market access, and more sustainable management of resources. Issues affecting land use arrangements, which often directly affect people's livelihoods, can result in high levels of social unrest. Also constant revocation of someone else land to give to another often results in land disputes and increase tenure insecurity thereby reducing investment potential in an economy.

\section{Implications of non-Affordable system}

High transaction cost of land charges gives opportunities for inappropriate practices such as bribery as there will be fewer formal transaction and avoidance of formal land market. It discourages registration and consequently investments on land. Informal land transactions to obtain access to land are one of the major avenues left to the landless; this is illustrated by informal settlements or squatting. The effect of high cost decreases revenue collection and widespread loss of credibility for formal land administration and the ultimate effect of impaired economic and social performance (Antonio, 2010). Land in FCT is owned by the government, these vested interests gain more by keeping the land while they profit from the status quo, and the prime losers are the urban residents, particularly the urban poor.

\section{Implications of Inefficiency}

Efficiency in land administration systems are a prerequisite for well-functioning cities. Government is charged with the responsibility of providing infrastructure in all the districts in the FCT. It has been observed that the average time lag between the announcement of a land development scheme and actual delivery of serviced plots can take an indefinite 
period. The implication of these increases pressure on serviced lands and properties in phase 1 due to high demand. This affects house rent generally in the FCT which is also at an exorbitant price. When the prices of accommodation both for residential and commercial uses are high, it will affect the cost of living and increase the cost of doing business in the city and adversely affects the urban economy of FCT. FCT suffers from distortions caused by inefficiency in land allocation in districts without infrastructure. This is a major factor that has encouraged land speculation and poor functioning of land market.

\section{Implications of lack of Transparency}

Corruption and abuse of power can adversely impact the business climate, economic activities, and increase cost of doing business. It prevents potential investors from investing in the city as reputable international businesses will avoid countries where they have to compromise their integrity and principles. Constant revocation of peoples plots due to vested interest has resulted in tenure insecurities. The consequences include tenure insecurity, exclusion on access to land, limited land markets, and increased land disputes between individuals. Functional ambiguity in AGIS makes it out of touch with people's expectations and desires. AGIS have allowed for land speculation which has priced the majority out of the formal land markets, into the informal land markets. People are also at high risk of purchasing forged land allocation. This has given rise to slums, squatter settlements and illegal sub-divisions especially in the satellite towns.

\section{CONCLUSION}

This study has examined the effects of AGIS on implementation of electronic land administration in FCT, Abuja Nigeria. The findings of the study revealed that AGIS to a certain extent has been a worthwhile exercise which has improved land administration from manual operation to computerization. However, it has not incorporated properly the norms of governance in land administration. Integrating good governance in land administration will offer various ways to improving the actual situation, supported by an appropriate land administration reform implementation. Electronic Land administration must be based on enlightened discourse and best practices. Any land administration reforms should have underlying well thought out goals. It is those goals that would guide the reform purposes and successful implementation. The study findings revealed that the starting point of the land administration reforms should address attendant issues of availability of land, security of tenure, ease of transaction as well as the timeliness with which processed land is made available in adequate amounts at right locations and at affordable prices to the people in a way to ensure its optimum use in terms of efficiency, equity and meeting of basic human needs. When good governance in land administration exists, decision-making is more transparent and participatory, the rule of law is applied equally to all, it will contribute to a simplified land administration and more sustainable urban development.

\section{RECOMMENDATIONS}

Based on the findings, the study recommended the following;

i. $\quad$ AGIS electronic Land Administration should operate with Fairness and Equity: Land policy reform is the foundation on which the systems in a country for land management and development are built. It must encourage efficient and maximum utilization of land through land market with the forces of demand and supply interacting. Such land administration reform should provide access to land for all irrespective of social and economic status; and should be compatible with existing policy instruments for economic development which should integrate well.

ii. It is recommended that the overall electronic land administration process of service delivery should be seen as business rather than bureaucratic processes. Streamlining of process flows is an essential part of achieving efficiency. Customer interface is a key element to improving AGIS's image. AGIS workflow should be reorganized and state-of-the art technology installed.

iii. There should be client survey to gain insight into the level of awareness and knowledge of customers regarding service standards, performance in delivering services, and degree of client satisfaction with the operation of the system and stakeholders views of shortcomings in the system function. Therefore, processes and procedures available for the acquisition of land should be clear, understood by the general public and delivered to users in a timely manner in accord with the set service standards.

iv. AGIS should decentralize its operations and computerize the area council zonal land offices. Efficiency often requires some level of service to be decentralized. This will maximize the potential for inclusion of the citizenry in the process of e-land governance at the grass root.

v. The study recommends Public Access to Cadastre via Internet - Web Based Electronic Land Information System: AGIS should publicly make available digital cadastral data and ownership information through the net i.e., converting land registry paper-based information to digital information and making it available online. This will reduce time for clients to complete the required processing through easy and fast access to cadastral data and land registry information from home or internet cafes. 


\section{REFERENCES}

Antonio, D. (2010). Instituting good governance in the land administration system - the Philippines' perspective.

Deininger, Klaus (2014). Land Policies for Growth and Poverty Reduction: Key Issues and Challenges Ahead. International Federation of Surveyors

Federal Capital Development Authority (FCDA)(2018). Retrieved February 30, 2018

from http://fcda.gov.ng/index.php/about-fcda/the-geography-of-abuja 